\title{
Pengaruh Net Profit Margin, Debt to Equity Ratio dan Inventory Turnover terhadap Harga Saham pada Perusahaan Consumer Goods Industry yang terdaftar di Bursa Efek Indonesia
}

\author{
Herlina Novita \\ Universitas Prima Indonesia \\ dhabitaziggy@gmail.com
}

\author{
Alex Candra Situmorang \\ Universitas Prima Indonesia \\ alexcandrasitumorangacc@gmail.com
}

\begin{abstract}
ABSTRAK
Penelitian ini bertujuan untuk menguji apakah Net profit margin, Debt to Equity Ratio dan Inventory Turnover memiliki pengaruh terhadap Harga Saham pada perusahaan Consumer Goods Industry yang terdaftar di Bursa Efek Indonesia. Penelitian ini merupakan jenis penelitian deskriptif kuantitatif, yang menggunakan data dari 37 perusahaan Consumer Goods Industry yang terdaftar di Bursa Efek Indonesia. Metode pengambilan sampel yang digunakan dalam penelitian ini adalah Purposive sampling dan diperoleh sampel sebanyak 14 sampel. Data yang digunakan adalah laporan keuangan dari masing-masing perusahaan sampel yang dipublikasikan melalui situs $w w w . i d x . c o . i d$. Adapun variabel yang berkaitan dalam penelitian ini adalah Net Profit Margin, Debt to Equity Ratio dan Inventory Turnover. Metode penelitian yang digunakan adalah metode analisis deskriptif dan metode analisis regresi linear berganda.Hasil penelitian ini menunjukkan bahwa secara parsial Net Profit Margin berpengaruh positif dan signifikan terhadap Harga Saham, sedangkan Debt to Equity Ratio tidak berpengaruh dan tidak signifikan terhadap Harga Saham dan juga Inventory Turnover berpengaruh negatif dan signifikan terhadap Harga Saham pada perusahaan Consumer Goods Industry yang terdaftar di Bursa Efek Indonesia. Hasil penelitian lain juga menunjukkan bahwa secara simultan Net Profit Margin, Debt to Equity Ratio dan Inventory Turnover bersama-sama berpengaruh signifikan terhadap Harga Saham pada perusahaan Consumer Goods Industry yang terdaftar di Bursa Efek Indonesia.
\end{abstract}

Kata Kunci :Net Profit Margin, Debt to Equity Ratio, Inventory Turnover dan Harga Saham

\section{Pendahuluan}

1.1 Latar Belakang Masalah

Bursa efek merupakan pasar modal terbesar di Indonesia yang di mana saham atau efek diperjualbelikan secara umum bagi para investor. Bursa Efek atau bursa saham adalah sebuah pasar yang berhubungan dengan pembelian dan penjualan efek perusahaan yang sudah terdaftar di bursa efek.

Saham merupakan suatu bukti tanda kepemilikan sebuah perusahaan. Saham dapat didefenisikan sebagai tanda penyertaan modal seseorang atau pihak (badan usaha) dalam suatu perusahaan atau perseroan terbatas, Saham bisa disebut juga sebagai salah satu instrument pasar keuangan yang paling populer. Menerbitkan saham merupakan salah satu pilihan perusahaan ketika memutuskan untuk pendanaan perusahaan. 
Net Profit Margin merupakan salah satu rasio profitabilitas yang digunakan untuk mengukur total laba bersih terhadap total penjualan bersih. Margin laba bersihsering digunakan oleh para investor untuk mengukur seberapa efisien manajemen pengelolaan perusahaannya dan juga memperkirakan profit masa depan berdasarkan peramalan penjualan yang dibuat oleh manajemennya.

Debt to Equity Ratio merupakan rasio yang digunakan untuk menilai utang terhadap ekuitas. Rasio ini dihitung dengan cara membandingkan antara total utang, dengan total ekuitas. Rasio ini diguna untuk menghitung berapa besar dana yang disediakan oleh peminjam (kreditor) dengan pemilik perusahaan. Perusahaan dengan arus kas yang stabil biasanya memiliki rasio lebih tinggi dari rasio kas yang kurangstabil.

Inventory Turn Over biasa digunakan untuk mengukur berapa kali dana yang ditanam dalam sediaan (Inventory) ini berputar dalam suatu periode. Rasio ini dikenal dengan nama rasio perputaran sediaan (Inventory Turn Over). Dapat diartikan pula bahwa perputaran sediaan merupakan rasio yang menunjukkan berapa kali jumlah barang

Table 1.1 Teori Pengaruh

Pengaruh Net Profit Margin(NPM), Debt to Equity Ratio (DER) dan Inventory Turnover (ITO) terhadap harga saham pada sector Consumer Goods Industry yang terdaftar di Bursa Efek Indonesia.

(Rupiah)

\begin{tabular}{|c|c|c|c|c|c|c|}
\hline $\begin{array}{c}\text { Nama } \\
\text { Perusahaan }\end{array}$ & $\begin{array}{c}\text { Kode } \\
\text { Perusahaan }\end{array}$ & Periode & Laba Bersih & Total Utang & Penjualan & $\begin{array}{c}\text { Harga } \\
\text { Saham }\end{array}$ \\
\hline \multirow{3}{*}{$\begin{array}{c}\text { PT. Kimia Farma } \\
\text { (Persero) Tbk }\end{array}$} & \multirow{2}{*}{ KAEF } & 2014 & 236.531 .070 .864 & 1.157 .040 .676 .384 & 4.521 .024 .379 .759 & 1.465 \\
\cline { 3 - 7 } & & 2016 & 252.972 .506 .074 & 1.374 .127 .253 .841 & 4.860 .371 .483 .524 & 870 \\
\cline { 3 - 7 } & & 2017 & 271.597 .947 .663 & 2.341 .155 .131 .870 & 5.811 .502 .656 .431 & 2.750 \\
\cline { 3 - 7 } & & 2014 & 2.531 .681 .000 .000 & 9.870 .264 .000 .000 & $30.022 .463 . .000 .000$ & 13.100 \\
\hline \multirow{2}{*}{$\begin{array}{c}\text { InT. } \\
\text { CBPSukses } \\
\text { Makmur Tbk }\end{array}$} & \multirow{2}{*}{ ICBP } & 2015 & 2.923 .148 .000 .000 & 10.173 .713 .000 .000 & 31.741 .094 .000 .000 & 13.475 \\
\cline { 3 - 7 } & & 2016 & 3.631 .301 .000 .000 & 10.401 .125 .000 .000 & 34.466 .069 .000 .000 & 8.575 \\
\cline { 3 - 7 } & & 2017 & 3.543 .173 .000 .000 & 11.295 .184 .000 .000 & 35.606 .593 .000 .000 & 8.900 \\
\hline
\end{tabular}




\begin{tabular}{|c|c|c|c|c|c|c|}
\hline & 2014 & 112.747 .505 .175 & 478.482 .577 .195 & 1.661 .533 .200 .316 & 640 \\
\cline { 3 - 7 } $\begin{array}{c}\text { PT. } \\
\text { Wismilak } \\
\text { IntiMakmur Tbk }\end{array}$ & \multirow{2}{*}{ WIIM } & 2015 & 125.706 .275 .922 & 398.991 .064 .485 & 1.839 .419 .574 .956 & 455 \\
\cline { 3 - 7 } & 2016 & 99.950 .660 .578 & 362.540 .740 .471 & 1.685 .795 .530 .617 & 456 \\
\cline { 3 - 7 } & 2017 & 19.591 .392 .031 & $247.620 .731 . .930$ & 1.476 .427 .090 .781 & 308 \\
\hline
\end{tabular}

Sumber: Bursa Efek Indonesia (Diolah oleh peneliti)

Berdasarkan tabel 1.1 di atas, dapat dilihat bahwa pada perusahaanPT. Kimia Farma (Persero) Tbk (KAEF), mengalami kenaikan laba bersih dari $\mathrm{Rp}$ 271.597.947.663 pada tahun 2016 menjadi $\mathrm{Rp} 331.707 .917 .461$ di tahun 2017. Sedangkan harga saham mengalami penurunan dari $\mathrm{Rp} 2.750$ pada tahun 2016 menjadi Rp 2.700 di tahun 2017. Yang seharusnya harga saham mengalami peningkatan karena meningkatnya lababersih.

Pada perusahaan PT. Indofood CBP Sukses Makmur Tbk (ICBP) mengalami kenaikan total utang $\mathrm{Rp}$ 9.870.264.000.000 pada tahun 2014 menjadi

Rp10.173.713.000.000.Sedangkanharga sahammengalamipeningkatandariRp

13.100 di tahun 2014 menjadi Rp 13.475 di tahun 2015. Yang seharusnya harga saham mengalami penurunan dikarenakan naiknya total utang.

Pada perusahaan PT. Wismilak Inti Makmur Tbk (WIIM), mengalami kenaikan penjualan dari Rp 1.661.533.200.316 di tahun 2014 menjadi Rp 1.839.419.574.956 pada tahun 2015. Sedangkan harga saham mengalami penurunan dari $\mathrm{Rp} 640$ pada tahun 2014 menjadi $\mathrm{Rp} 455$ di tahun 2015. Yang seharusnya harga saham mengalami kenaikan dikarenakan meningkatnya penjualan.

\section{Tinjauan Pustaka}

2.1.1 Teori Pengaruh Net Profit Margin (NPM) terhadap hargasaham

Apabila margin laba bersih semakin tinggi maka semakin tinggi juga laba bersih yang harus dihasilkan dari penjualan bersih(Hery, 2015).

Rasio ini digunakan untuk mengukur hasil akhir dari seluruh kegiatan perusahaan. Selisih laba bersih dengan laba usaha menunjukkan seberapa besar beban yang harus ditanggung perusahaan untuk beban non operasional (Prihadi, 2011).

Net Profit Margin (NPM) mencerminkan tingkat kemampuan perusahaan dalam memperoleh laba dari kegiatan usaha tertentu. Jika Net Profit Margin semakin tinggi maka suatu perusahaan semakin efektif dalam menjalankan kegiatan operasinya(Hani, 2015).

\subsubsection{Indikator Net Profit Margin (NPM) terhadap Harga Saham \\ Net Profit Margin (Margin Laba} Bersih) adalah rasio yang digunakan dalam menghitung tingkat laba bersih setelah pajak lalu dibandingkan dengan jumlah volume penjualan(Wardiyah, 2017).

Net Profit Margin $=\frac{\text { Laba setelah } \text { pajak }}{\text { Penjualan Bersih }}$

\subsubsection{Teori Pengaruh Debt to Equity Ratio (DER) terhadap HargaSaham}

Rasio ini digunakan untuk mengukur selisih antara utang dengan ekuitas. Rasio ini mencerminkan jumlah utang dengan ekuitas. Jika semakin tinggi rasio ini maka semakin tinggi resiko kerugian perusahaan(Prihadi, 2011).

Apabila Debt to Equity Ratio semakin tinggimaka semakin kecil juga jumlah modal pemilik yang bisa 
dijadikan sebagai jaminan utang perusahaan(Hery, Analisis Kinerja Manajemen, 2014).

Rasio ini digunakan untuk mengukur jumlah dana yang dapat disediakan oleh kreditor dan dana yang telah disediakan oleh pemilik(Samryn, 2014).

\subsubsection{Indikator Debt to Equity Ratio(DER) terhadap Harga Saham}

Apabila rasio ini semakin tinggi, maka menunjukkan semakin tinggi pula jumlah dana dari luar yang harus dijamin dengan jumlah modal sendiri(Hani, 2015).

Debt to Equity Ratio $=\frac{\text { Total Liabilities }}{\text { Total Equity }}$

\subsubsection{Teori Pengaruh Inventory Turnover(ITO) terhadap Harga Saham}

jika semakin rendah rasio perputaran persediaan maka menunjukkan bahwa semakin banyak persediaan barang dagang yang ada di gudang disebabkan oleh lama proses penjualan persediaan, dan hal ini juga dapat mengakibatkan tingkat pengembalian investasi yang rendah(Hery, Teori Akuntansi : Pendekatan konsep dan analisis, 2017).

Rasio ini menunjukkan seberapa cepat perputaran persediaan dalam siklus produksi normal(Harahap, 2011).

Rasio ini menunjukkan berapa kali rata-rata persedian barang jadi berputar atau terjual dalam suatu periode waktu terntentu dan biasanya setahun(Samryn, 2014).

\subsubsection{Indikator Turnover(ITO) terhadap Harga Saham}

menunjukkan kemampuan dana yang tertanam dalam persdiaan yang berputar dalam satu periode tertentu atau likuiditas dari persediaan dan tendensi untuk adanya "overstock"(Sujarweni, 2017).

Inventory turnover $=\frac{\text { Harga pokok produk }}{\text { Inventory rata-rata }}$

\subsection{Pengertian HargaSaham}

Harga saham merupakan surat berharga yang di perjualbelikan di bursa saham dan harga yang tertera di saham tersebut dijadikan sabegai nilai atas kepemilikan perusahaan"(Kodrat \& Indonanjaya, 2010).

saham merupakan salah satu tanda bukti penyertaan modal/dana atau tanda kepemilikan pada suatu perusahaan (Fahmi, 2015).

Saham adalah salah satu komoditas keuangan yang diperjualbelikan di Bursa Efek Indonesia. Investasi saham oleh investor diharapkan memberikan keuntungan(Hadi, 2015).

\subsection{Kerangka Konseptual}

Adapun kerangka konseptual dari penelitian ini dapat digambarkan sebagai berikut :

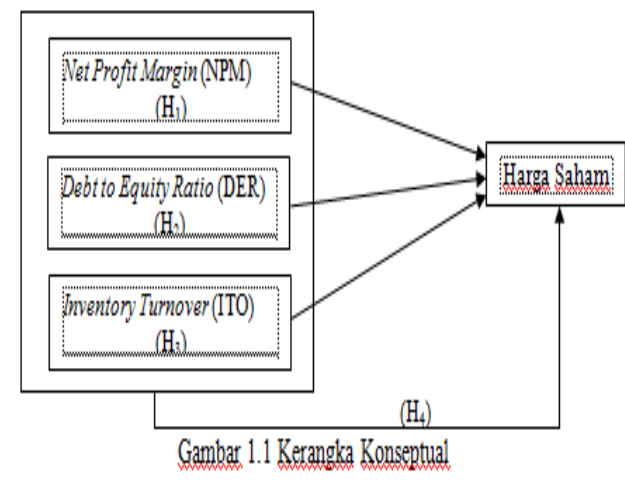

\subsection{Hipotesis Penelitian}

Hipotesis dapat diartikan sebagai jawaban yang bersifat sementara terhadap masalah yang diajukan dan jawaban itu masih akan diuji secara empiris kebenarannya. Hipotesis dalam penelitian ini adalah :

$\mathrm{H}_{1}$ : Net Profit Margin (NPM)berpengaruh terhadap harga saham pada sektor Consumer Goods Industry yang terdaftar di Bursa 
Efek Indonesia.

$\mathrm{H}_{2}$ : Debt to Equity Ratio (DER)berpengaruh terhadap harga saham pada sektor Consumer Goods Industry yang terdaftar di Bursa Efek Indonesia

$\mathrm{H}_{3}$ : Inventory Turnover (ITO)berpengaruh terhadap harga saham pada sector Consumer Goods Industry yang terdaftar di Bursa Efek Indonesia.

$\mathrm{H}_{4}$ : Net Profit Margin(NPM), Debt to Equity Ratio (DER|), Inventory Turnover (ITO) berpengaruh terhadap harga saham pada sektor Consumer Goods Industry yang terdaftar di Bursa Efek Indonesia.

\section{Metodologi Penelitian}

Penelitian Kuantitatif merupakan salah satu jenis penelitian yang menghasilkan penemuanpenemuan yang dapat dicapai dengan menggunakan prosedur-prosedur statistik atau cara-cara lain dari kuantitatif (pengukuran). Pendekatan kuantitatif memusatkan perhatian pada gejala-gejala yang mempunyai karakteristik tertentu di dalam kehidupan manusia yang dinamakan sebagai variabel. Dalam pendekatan kuantitatif hakekat hubungsn di antara variabelvariabel dianalisis dengan menggunakan toeri yangobjektif. Pada penelitian ini, peneliti menggunakan metodologi penelitiankuantitatif(Sujarweni V. W., 2014)

\subsection{Variabel Penelitian}

Variabel penelitian merupakan salah satu atribut atau sifat nilai dari objek, kegiatan yang mempunyai variabel tertentu yang ditetapkan oleh peneliti untuk dipelajari sehingga mendapatkan kesimpulan dari penelitian tersebut. Dalam penelitian ini terdapat 2 variabel yaitu variabel dependen dan variabel independen(Trijono, 2015).

Variabel dependen dalam penelitian ini adalah harga saham. Harga saham yang digunakan dalam penelitian ini berdasarkan harga pasar saham di Bursa Efek Indonesia saat ini. Harga saham yang digunakan adalah harga penutup atau Closing Price, yang merupakan harga akhir dalam transaksi jual-beli saham di Bursa Efek Indonesia. Variabel Independen dalam penelitian ini adalah Net Profit Margin (NPM), Debt to Equity Ratio (DER), Inventory Turnover (ITO). Variabel independen sering juga dikatakan sebagai variabel bebas yang mempengaruhi atau yang menjadi sebab perubahan atau timbulnya variabel dependen.

\subsection{Populasi dan Sampel \\ 3.2.1 Populasi}

Populasi merupakan jumlah keseluruhan kumpulan elemen yang menunjukkan ciri-ciri tertentu yang dapat digunakan untuk membuat kesimpul(Sanusi, 2011). Jadi kumpulan elemen itu menunjukkan jumlah, sedangkan cirri-ciri tertentu menunjukkan karateristik dari kumpulan itu. populasi dalam penelitian ini adalah berjumlah 37 perushaaan di sektor Consumer Goods Industry yang terdaftar di Bursa Efek Indonesia.

\subsubsection{Sampel}

Sampel merupakan bagian dari populasi yang dipilih berdasarkan kriteria dalam penelitian. Dapat berupa individu yang berdiri sendiri atau kumpulan individu(Sanusi, 2011).

Berdasarkan pengamatan yang dilakukan jumlah populasi dalam penelitian ini berjumlah 37 perusahaan sektor Consumer Goods Industry yang terdaftar di Bursa Efek Indonesia. Penerikan sampel dilakukan dengan beberapa kriteria dan dijelaskan pada tabel di bawah. 


\begin{tabular}{|c|c|c|}
\hline $\mathrm{No}$ & Kriteria & $\begin{array}{c}\text { Jumlah } \\
\text { populasi }\end{array}$ \\
\hline 1 & 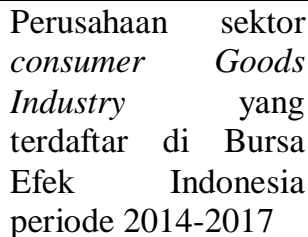 & 37 \\
\hline 2 & 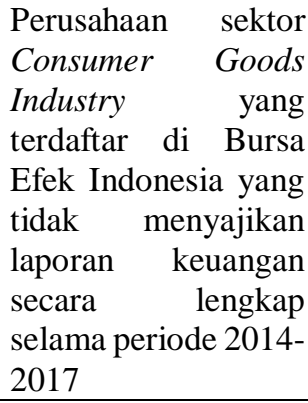 & (9) \\
\hline 3 & $\begin{array}{l}\text { Perusahaan sektor } \\
\text { Consumer Goods } \\
\text { Industry yang } \\
\text { terdaftar di Bursa } \\
\text { Efek Indonesia yang } \\
\text { memiliki laba negatif } \\
\text { selama periode 2014- } \\
2017\end{array}$ & $(9)$ \\
\hline 4 & $\begin{array}{lr}\text { Perusahaan } & \text { sektor } \\
\text { Consumer } & \text { Goods } \\
\text { Industry } & \text { yang } \\
\text { terdaftar di } & \text { Bursa } \\
\text { Efek Indonesia yang } \\
\text { tidak } & \text { menyajikan } \\
\text { laporan } & \text { Annual } \\
\text { Report } & \text { secara } \\
\text { lengkap } & \text { selama } \\
\text { periode } & 2014-2017\end{array}$ & $(5)$ \\
\hline \multicolumn{2}{|c|}{ Jumlah Sampel } & 14 \\
\hline \multicolumn{2}{|c|}{ Tahun Pengamatan } & 4 \\
\hline \multicolumn{2}{|c|}{$\begin{array}{l}\text { Total sampel selama } \\
\text { periode berjalan }(14 \times 4)\end{array}$} & 56 \\
\hline
\end{tabular}

Berdasarkan tabel di atas ada beberapa kriteria dalam pengambilan sampel dalam penelitian ini. Dengan melakukan pemeriksaan laporan keuangan pada perusahaan sektor Consumer Goods Industry yang terdaftar di Bursa Efek indonesia yang tidak menyajikan laporan keuangan dan annual report secara lengkap selama periode 2014-2017 dan juga melakukan permeriksaan perusahaan pada sektor Consumer Goods Industry yang terdaftar di Bursa Efek Indonesia yang memiliki laba negatif selama periode 2014-2017. Dengan kriteria ini peneliti melakukan penarikan sampel. Berdasarkan kriteria tersebut jumlah sampel yang di peroleh ada 14 perusahaan dan ada 23 perusahaan yang tidak di jadikan karna memiliki kriteria dalam penarikan sampel dalam penelitian ini. Peneliti menyimpulkan bahwa sampel dalam penelitian ini ada berjumlah 14 perusahaan dan di kali 4 tahun pengamatan dan total sampel selama periode tahun berjalan ada 56 sampel.

\subsection{Teknik Analisis Data 3.3.1 Uji Analisis Regresi Linear Berganda}

Sanusi (2011:134) Regresi linier berganda pada dasarnya adalah sebuah perluasan dari regresi linier sederhana, yaitu menambah jumlah variabel bebas yang sebelumnya hanya satu menjadi dua atau lebih variabel bebas. Pada penelitian ini, ada tiga variabel bebas (independen) dan satu variabel terikat (dependen), Dengan demikian, regresi linier berganda dapat dirumuskan dengan: $\mathrm{Y}=$ $a+b 1 X 1+b 2 \times 2+b 3 \times 3+e$

\section{Uji F}

Menurut Ghozali (2016: 96) Uji F menguji joint hipotesia bahwa b1, b2 dan b3 secara simultan sama dengan nol, atau:

$\mathrm{H} 0: \mathrm{b} 1=\mathrm{b} 2=\ldots \ldots \ldots=\mathrm{bk}=0$
$\mathrm{Ha}: \mathrm{b} 1 \neq \mathrm{b} 2 \neq \ldots \ldots \ldots . \neq \mathrm{bk} \neq 0$

Uji hipotesis seperti ini dinamakan uji signifikansi secara keseluruhan terhadap garis regresi yang diobservasi maupun estimasi, apakah Y berhubungan linier terhadap X1, X2 dan X3. Untuk memenuhi hipotesis ini digunakan statistik $\mathrm{F}$ dengan kriteria pengambilan keputusan sebagai berikut:

a. Quick look: bila nilai $\mathrm{F}$ lebih besar daripada 4 maka Ho dapat ditolak pada derajat kepercayaan 5\%., dengan kata lain kita menerima 
hipotesis alternatif, yang menyatakan semua variabel independen secara serentak dan signifikan mempengaruhi variabeldependen.

b. Membandingkan nilai $F$ hasil perhitungan dengan nilai $\mathrm{F}$ menurut tabel. Bila nilai $\mathrm{F}$ hitung lebih besar daripada nilai $\mathrm{F}$ tabel, maka $\mathrm{Ho}$ ditolak dan menerimaHa.

\section{Uji t}

Uji statistik $t$ pada dasarnya menunjukkan seberapa jauh pengaruh satu variabel penjelas/independen secara individual dalam menerangkan variasi variabel dependen. Hipotesis nol (H0) yang hendak diuji adalah apakah suatau parameter (bi) sama dengan nol, atau : H0 : bi = 0(Ghozali, 2016).

Artinya apakah suatu variabel independen bukan merupakan penjelas yang signifikan terhadap variabel dependen. Hipotesis alternatifnya (HA) parameter suatu variabel tidak sama dengan nol, atau:

Ha : bi $\neq 0$

Artinya, variabel tersebut merupakan penjelas yang signifikan terhadap variabel dependen.

Cara melakukan uji $\mathrm{t}$ adalah sebagai berikut:

1. Quick look: bila jumlah degree of freedom (df) adlah 20 atau lebih, dan derajat kepercayaan sebesar 5\%, maka Ho yang menyatakan $\mathrm{bi}=0$ dapat ditolak bila nilai t lebih dari 2(dalam nilai absolut). Dengan kata lain kita menerima hipotesis alternatif, yang menyatakan bahwa suatu variabel independen secara individual mempengaruhi variabeldependen.

2. Membandingkan nilai statistik $\mathrm{t}$ denngan titik kritis menurut tabel. Apabila nilai statistik $\mathrm{t}$ hasil perhitungan lebih tinggi dibandingkan nilai t tabel, kita menerima hipotesis alternatif yang menyatakan bahwa suatu variabel independen secara individual mempengaruhi variabeldependen.

\subsubsection{Uji Asumsi Klasik \\ 1. Uji Multikolonieritas}

Uji multikolonieritas bertujuan untuk menguji apakah model regresi ditemukan adanya kelorasi antar variabel bebas (independen) model regresi yang baik seharusnya tidak terjadi kolerasi di antara variabelindependen(Ghozali, 2016).

\section{Uji Autokorelasi}

Uji Autokolerasi bertujuan mengujji apakah dalam model regresi linier ada kolerasi antara kesalahan penggangu pada periode $t$ dengan kesalahan pengganggu pada peride $\mathrm{t}-1$ (sebelumnya).

\section{Uji Heteroskedastisitas}

Uji Heteroskedastisitas yang bertujuan menguji apakah dalam model regresi terjadi ketidaksamaan variance dari rasidual satu pengamatan ke pengamatan yang lain. Jika variance dari rasidual satu pengamatan ke pengamatan yang lain tetap, maka disebut homoskedastisitas dan jika berbeda disebut heteroskesdatisitas.

\section{Uji Normalitas}

Uji Normalitas bertujuan untuk menguji apakah dalam model regresi, variabel penggangu atau residual memiliki distribusi normal. Seperti diketahui bahwa uji $t$ dan $f$ mengasumsikan bahwa nilai residual mengikuti distribusi normal.

\section{Hasil Dan Pembahasan \\ 4.1 Uji Asumsi Klasik}

Uji asumsi klasik digunakan sebagai syarat dalam melakukan model regresi agar hasil regresi yang di peroleh merupakan estimasi yang tepat 
1

Uji Normalitas

Uji Normalitas bertujuan untuk mengetahui apakah dalam model regresi, variabel penggangu atau residual. Uji normalitas digunakan untuk menguji apakah data berdistribusi dengan normal ataui tidak dengan melalukan analisi:

\section{a. Analisis Grafik}

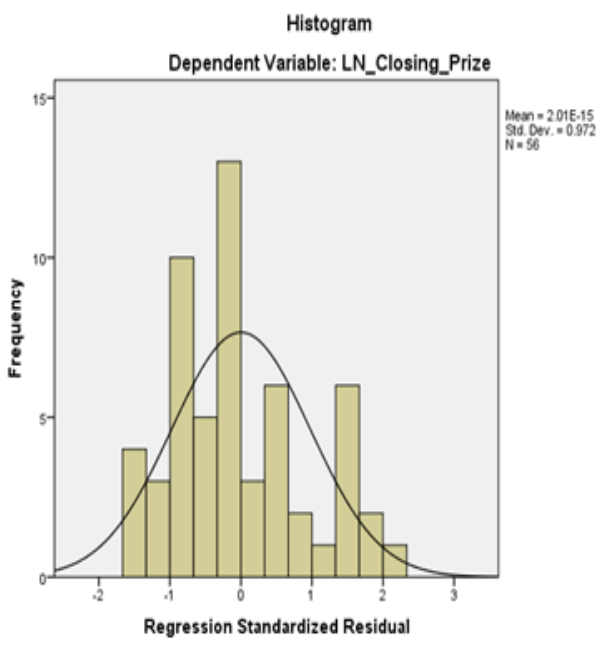

Gambar 3.1

Uji Normalitas - Histogram

Berdasarkan tampilan grafik histogram pada gambar 4.1 di atas menunjukkan garis kurva berada di tengah dan tidak dominan ke kiri ataupun ke kanan sehingga hal ini dapat dikatakan bahwa residual yang dihasilkan berdistribusi secara normal

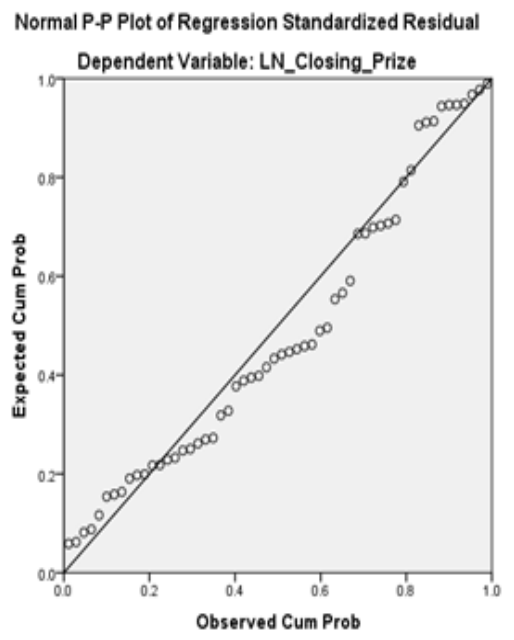

Gambar 3.2

Uji Normalitas - Probability Plot

Berdasarkan tampilan grafik Normalitas Probability Plot pada gambar 4.2 dapat dilihat menunjukkan titik-titik yang ada mengikuti garis diagonal sehingga dapat disimpulkan bahwa data berdistribusi normal.

\section{b. Analisis Statistik}

Tabel 4.1

Uji Normalitas - Kolmogorov Smirnov

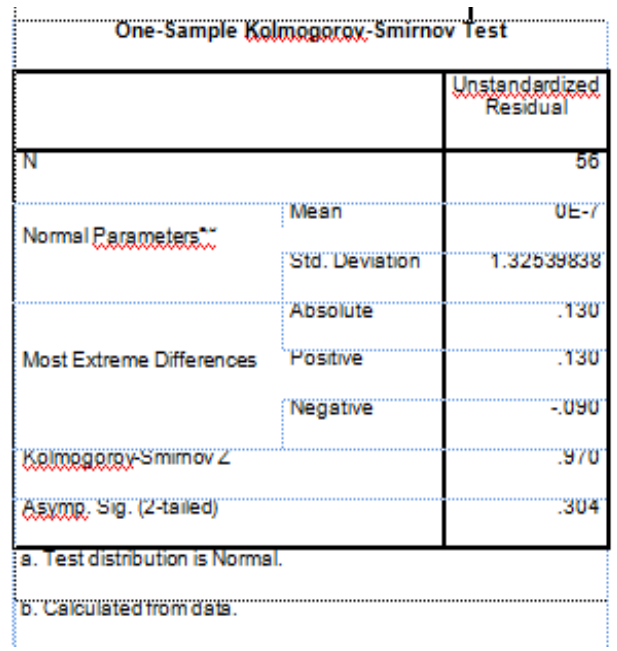

Berdasarkan hasil Uji

Kolmogorov Smirnov pada tabel $4.1 \mathrm{di}$ atas menunjukkan bahwa variabel NPM $\left(\mathrm{X}_{1}\right)$, DER $\left(\mathrm{X}_{2}\right)$, ITO $\left(\mathrm{X}_{3}\right)$ dan Harga 
Saham (Y) dapat dikatakan berdistribusi normal. Hal ini terlihat dari hasil uji Kolmogorov Smirnov menunjukkan nilai Aysmp.sig.(2-tailed) sebesar 0,0861 lebih besar dari 0,05 .

\section{Uji Multikoleneritas}

Uji multikoleneritas bertujuan untuk menguji apakah model regresi ditemukan adanya korelasi antar variabel beban (independen). Pengujian multikolineritas dilakukan dengan melihat VIF antar variabel independen.

Tabel 4.2

Uji Multikolineritas

\begin{tabular}{|c|c|c|c|c|c|c|}
\hline & & & (x) & & & \\
\hline Wod: & $\begin{array}{l}489 \\
6 n^{4}\end{array}$ & sting & 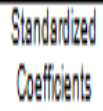 & $!$ & 8 & $\begin{array}{l}\text { Whent } \\
\text { Stitith }\end{array}$ \\
\hline & $B$ & Sid. & Bth & & & \begin{tabular}{|l|l} 
Tora: & WF \\
no:
\end{tabular} \\
\hline (Consint) & $\mid 1.81$ & 34 & & 13.96 & $\mathbb{M}$ & \\
\hline N MPN & 1.08 & $M$ & .7 & 3.360 & $\mathbb{M}$ & $96210 \%$ \\
\hline NDER & 25 & 17 & 16 & 1262 & W & $M: 1,07$ \\
\hline 10 & .221 & .149 & .18 & $0.1,84$ & .14 & 8911,198 \\
\hline
\end{tabular}

Berdasarkan tabel 4.2 di atas menunjukkan bahwa nilai tolerance variabel NPM sebesar 0,963 lebih besari dari 0,10 , nilai tolerance variabel DER sebesar 0,903 1 lebih besar dari 0,10, dan nilai tolerance variabel ITO sebesar 0,881 lebih besar dari 0,10. Dan nilai VIF variabel NPM 1,039 lebih kecil dari 10,00, nilai VIF variabel DER 1.107 lebih kecil dari 10,00, dan nilai VIF variabel ITO 1,135 lebih kecil dari 10,00. Dalam hal ini dapat menunjukkan bahwa nilai tolerance lebih besar dari 0,10 dan nilai VIF lebih kecil dari 10,00, maka dari hasil tersebut tidak terjadi multikolinearitas dan dapat disimpulkan tidak terjadi korelasi antar variabel independen.

\section{Uji Heteroskedastisitas}

Uji regresi dapat dilakukan baik jika tidak terjadi masalah heteroskedastisitas, dalam penelitian ini peneliti mengambil cara dengan menggunakan diagram chart (scatterplot). Dengan dasar pemikiran: 1) Jika ada pola terntu seperti titik-titik yang membentuk suatu pola tertentu yang teratur (bergelombang, melebar, kemudian menyempit) maka dapat dikatakan terjadi malasah heteroskedastisitas.

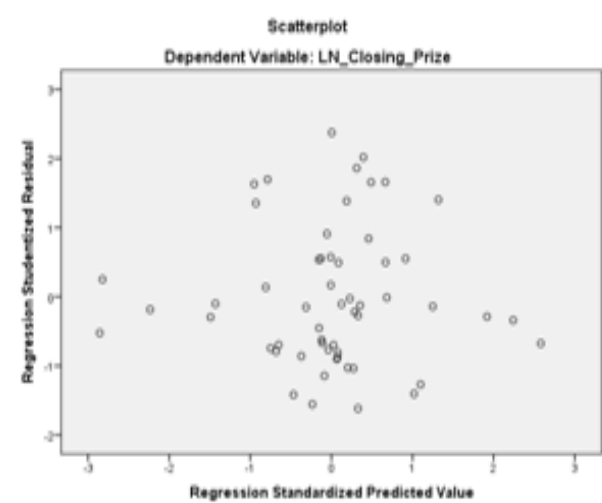

Gambar 4.3

\section{Uji Heteroskedastisitas - Scatterplot}

Berdasarkan tampilan pada gambar 4.3 di atas dapat dilihat bahwa titik-titik yang ada menyebar secara acak ke atas maupun ke bawah. Dengan demikian dapat disimpulkan bahwa tidak terjadi masalah heteroskedastisitas.

\section{Uji Autokorelasi}

Uji Autokorelasi bertujuan untuk menguji apakah model regresi linear ada korelasi antara kesalahan pengganggu pada periode $t$ dengan kesalahan pengganggu pada periode $\mathrm{t}-1$ (sebelumnya). Dalam penelitian ini test yang digunakan adalah Model Summary, dimana jika $\mathrm{d}<\mathrm{dl}$ atau $\mathrm{d}>4$-dl maka terdapat Autokorelasi,kemudian jika du < 
d $<4$-du maka tidak terdapat autokorelasi dan jika dl $<$ d $<$ du atau 4-du $<$ d $<4$-dl maka tidak ada kesimpulan. Dengan $d$ adalah nilai dari durbin Watson yang terdapat dalam tabel Model Summary, serta nilai dl dan du diperoleh dengan cara melihat jumlah sampel (n) dan jumlah variabel independen $(\mathrm{k})$ pada tabel Durbin Watson (DW) sesuai dengan data yang berkaitan.

Tabel 4.3

Uji Autokorelasi

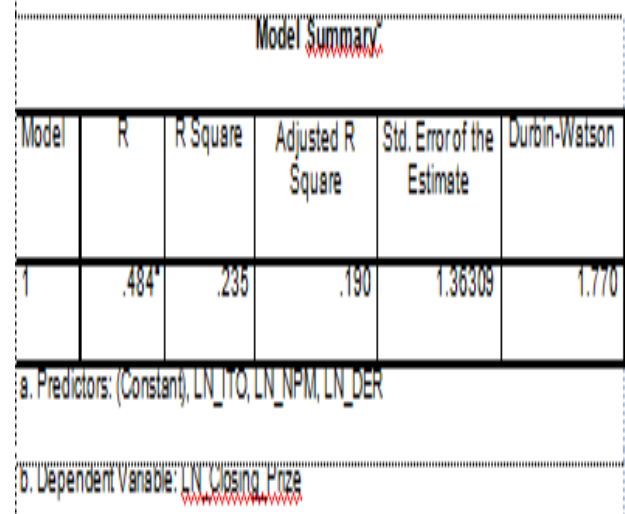

Dari hasil statistik pada tabel 4.3 di atas terlihat bahwa du $<$ d $<4$-du yakni $1,6830<1,703<2,3111$ maka tidak terdapat Autokorelasi.

\subsection{Uji Analisis Regresi Linear Berganda}

Analisis regresi linear berganda digunakan untuk mencari hubungan atau pengaruh antar variabel independen ( $\mathrm{Net}$ Profit Margin, Debt to Equity Ratio dan Inventory Turnover) terhadap variabel dependen (Harga Saham).

\section{Uji F}

Uji $f$ digunakan untuk menunjukkan apakah semua variabel independen yang dimasukkan dalam model mempunyai pengaruh secara bersama-sama terhadap variabel dependen.
Tabel 4.4

Uji F

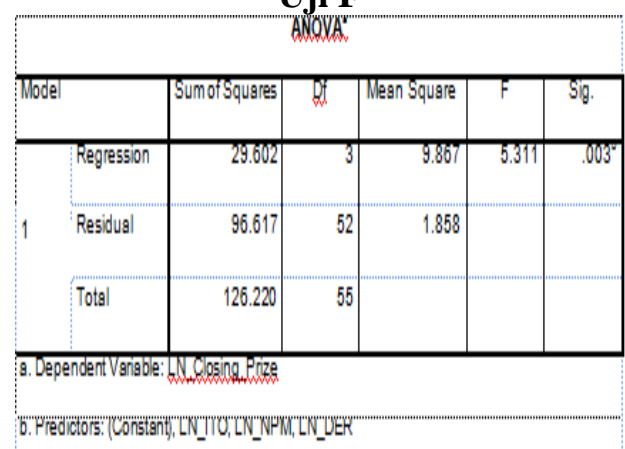

Dari hasil pengujian statistic pada tabel 4.4 diatas dapat dilihat bahwa nilai signifikan nya 0,003 dan lebih kecil dari 0,05 dan hasil $F_{\text {hitung }}$ menunjukkan nilainya sebesar 9.867 yang lebih besar dari $\mathrm{F}_{\text {tabel }}$ sebesar 2,78. $\mathrm{F}_{\text {tabel }}$ di dapat dari hasil perhitungan $\mathrm{F}(\mathrm{k} ; \mathrm{n}-\mathrm{k})=\mathrm{F}(3 ; 53)$ dan setelah dari $\mathrm{F}$ tabel menunjukkan bahwa hasilnya adalah 2,77. Dari hasil pengujian statistik tersebut variabel independen NPM $\left(\mathrm{X}_{1}\right)$, DER $\left(\mathrm{X}_{2}\right)$ danITO $\left(\mathrm{X}_{3}\right)$ berpengaruh terhadap variabel dependen Harga Saham (Y).

\section{Uji t}

Uji statistik $t$ pada dasarnya menunjukkan seberapa jauh pengaruh satu variabel penjelas/independen secara individual dalam menerangkan variasi variabel dependen. Hipotesis nol $\left(\mathrm{H}_{0}\right)$ yang hendak diuji adalah apakah suatu parameter (bi) sama dengan nol.

\section{Tabel 4.5}

Uji t

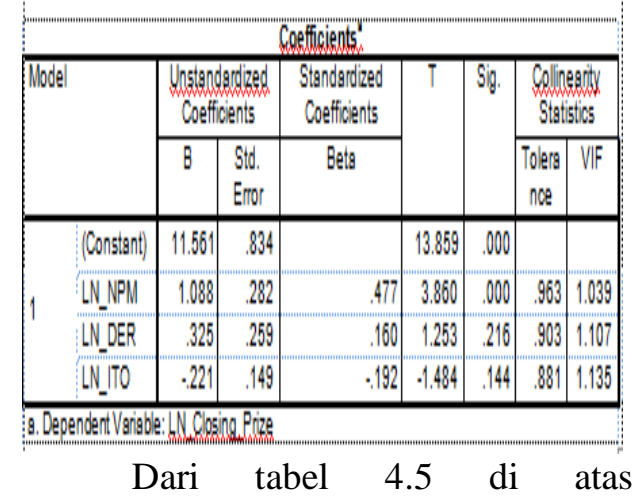


menunjukkan 0,000 lebih kecil dari0,05, dan hasil tersebut membuktikan bahwa NPM signifikan terhadap Harga Saham. Hasil lain juga terlihat dari $t_{\text {hitung }}$ sebesar 3,860 lebih besar dari tabel yaitu sebesar $1,674, t_{\text {tabel }}$ di dapat dengan rumus $(\alpha / 2$; n-k-1) yaitu $(0,05 ; 52)$ dan dari hasil tabel $t$ tersebut menunjukkan 1,674. Hal ini menunjukkan menerima hipotesisalternatif yang menyatakan bahwa suatu variabel independen secara individual mempengaruhi variabel dependen.

Pengujian terhadap DER juga dapat dilihat dari 0.216 lebih besar dari 0,05 , hal ini menunjukkan bahwa DER tidak signifikan terhadap Harga Saham. Sementara itu $t_{\text {hitung }}$ sebesar 1,253 lebih kecil dari tabel 1,672 hal ini menunjukkan menolak hipotesis alternatif DER.

Sementara itu pengujian terhadap ITO menunjukkan 0,144 lebih besar dari 0,05, hasil ini menunjukkan ITO tidak signifikan terhadap Harga Saham dan juga dilihat bahwa thitung sebesar - 1,484 lebih kecil dari tabel 1,672 hal ini menunjukkan menolak hipotesis alternatif ITO.

\subsection{Pembahasan Hasil Penelitian \\ 1. Pengaruh Net Profit Margin Terhadap Harga Saham \\ Dari hasil pengujian secara} parsial, dapat dilihat hasil pengujian statistik melalui SPSS menunjukkan bahwa pengujian terhadap NPM dilihat dari nilai sig pada tabel Coefficients yakni 0,000 lebih kecil dari 0.05 , hasil tersebut menunjukkan bahwa NPM signifikan terhadap Harga Saham. Hasil lain juga terlihat dari thitung sebesar 3,860 lebih besar dari tabel yaitu sebesar 1,674, $t_{\text {tabel }}$ di dapatdengan rumus $(\alpha / 2 ; n-k-1)$ yaitu $(0,05 ; 52)$ dan hasil tabel $\mathrm{t}$ menunjukkan 1,674. Hal ini menunjukkan menerima hipotesis alternatif yang menyatakan bahwa suatu variabel independen secara individual mempengaruhi variabel dependen.

\section{Pengaruh Debt to Equity Ratio Terhadap Harga Saham \\ Dari hasil pengujian secara} parsial, dapat dilihat hasil pengujian statistik melalui SPSS menunjukkan bahwa pengujian terhadap DER dilihat dari nilai sig pada tabel Coefficients yakni 0,216 lebih besar dari 0,05 , hal ini menunjukkan bahwa DER tidak signifikan terhadap Harga Saham. Sementara itu $t_{\text {hitung }}$ sebesar 1.253 lebih kecil dari tabel 1,672 hal ini menunjukkan menolak hipotesis alternatif DER.

\section{Pengaruh Inventory Turnover Terhadap Harga Saham \\ Dari hasil pengujian secara} parsial, dapat dilihat hasil pengujian statistik melalui SPSS menunjukkan bahwa pengujian terhadap ITO menunjukkan nilai sig pada tabel coefficients yakni $0.144>0,05$, hasil ini menunjukkan ITO tidak signifikan terhadap Harga Saham. Dan juga hal ini menunjukkan menolak hipotesis alternatif dapat dilihat bahwa thitung sebesar - 1,484 lebih kecil dari $t_{\text {tabell }}$ sebesar1,674.

\section{Kesimpulan Dan saran \\ 5.1 Kesimpulan \\ Dari hasil penelitian ini} diperoleh kesimpulan sebagai berikut : Net Profit Margin (NPM)secara parsial berpengaruh positif dan signifikan terhadap Harga Saham pada perusahaan Consumer Goods Industry yang terdaftar di Bursa Efek Indonesia, sehingga Hipotesis pertama $\left(\mathrm{H}_{1}\right)$ pada penelitian ini diterima dan hal ini menunjukkan bahwa kenaikan :

1. atau penurunan laba bersih dapat mempengaruhi Harga Saham perusahaan.

2. Inventory Turnover (ITO) secara parsial berpengaruh negatif dan tidak signifikan terhadap Harga 
Saham pada perusahaan Consumer Goods Industry yang terdaftar di Bursa Efek Indonesia, sehingga Hipotesis ketiga $\left(\mathrm{H}_{3}\right)$ pada penelitian ini diterima dan hal ini menunjukkan bahwa kenaikan atau penurunan persediaan dapat mempengaruhi Harga Saham perusahaan.

3. Net Profit Margin, Debt to Equity Ratio dan Inventory Turnover secara simultan berpengaruh dan signifikan terhadap Harga Saham pada perusahaan Consumer Goods Industry yang terdaftar di Bursa Efek Indonesia. Hal ini menunjukkan bahwa Hipotesis keempat $\left(\mathrm{H}_{4}\right)$ dapat diterima.

\subsection{Saran}

Saran yang diberikan peneliti berkaitan dengan hasil penelitian adalah:

1. Berdasarkan hasil penelitian, disarankan kepada perusahaan Consumer Goods Industry yang terdaftar di Bursa Efek Indonesia untuk terus-menerus mepertahankan laba, dikarenakan laba dapat memberikan efek pada perusahaan sehingga dampak tersebut juga didapat memberikan kesejateraan dan semangat kerja bagi para karyawan perusahaan. Selain itu, perusahaan juga harus memperhatikan efisiensi Net Profit Margin, Debt to Equity Ratio dan Inventory Turnover yang dapat meningkatkan Harga Saham Perusahaan.

\section{DAFTAR PUSTAKA}

Fahmi, I. (2015). Manajemen Investasi : Edisi 2. Jakarta: Salemba Empat.

Ghozali, I. (2016). Aplikasi Analisis Multivariete : Dengan Program IBM SPSS 23 Edisi 8. Semarang:
Iniversitas Diponegoro.

Hadi, N. (2015). Pasar Modal : Edisi 2. Yogyakarta: Graha Ilmu.

Hani, S. (2015). Teknik Analisa : Laporan Keuangan. Medan: UMSU Press.

Harahap, S. S. (2011). Teknik Analisa Kritis atas : Laporan Keuangan. Jakarta: PT Raja Grasindo Persada.

Hery. (2014). Analisis Kinerja Manajemen. Jakarta: PT Grasindo.

Hery. (2015). Analisis Laporan Keuangan : Pendekatan Rasio Keuangan. Yogyakarta: PT. Buku Seru.

Hery. (2017). Teori Akuntansi : Pendekatan konsep dan analisis. Jakarta: PT Grasindo.

Kodrat, D. S., \& Indonanjaya, K. (2010). Manajemen Investasi : Pendekatan Teknikal dan Fundamental untuk Analisis Saham. Yogyakarta: Graha Mulia.

Prihadi, T. (2011). Praktis Memahami : Laporan Keuangan Sesuai IFRS dan PSAK. Jakarta: PPM.

Samryn, L. M. (2014). Pengantar Akuntansi : mudah membuat jurnal dengan pendekatan siklus transaksi. Jakarta: PT Raja Grafindo Persada.

Sanusi, A. (2011). Metodlogi Penelitian Bisnis. Jakarta: Salemba Empat.

Sujarweni, V. W. (2017). Analisis Laporan Keuangan : Teori, Aplikasi dan Hasil Penelitian. Yogyakarta: Pustaka Baru Press.

Sujarweni, V. W. (2014). Metode Penelitian : Lengkap, praktis, dan mudah dipahami. Yogyakarta: Pustaka Baru Press.

Trijono, R. (2015). Metodologi Penelitian kuantitatif. Depok: Papas Sinar Sinanti.

Wardiyah, M. L. (2017). Analisis Laporan Keuangan. Bandung: CV Pustaka Setia. 